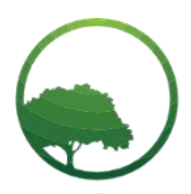

Research in Business \& Social Science

\title{
A comparative analysis of flexible working patterns in Germany and Turkey
}

\author{
Fulya Aydinli Kulak@(a), Vala Lale Tuzuner@(b) \\ (a,b)School of Business, Istanbul University, Istanbul, Turkey
}

\begin{tabular}{l} 
A R T I C L E I N F O \\
\hline Article history: \\
Received 05 June 2020 \\
Received in rev. form 25 June 2020 \\
Accepted 28 June 2020 \\
Keywords: \\
Flexible Working Patterns, Flexibility \\
in Working Life, COVID-19, \\
Pandemic, Germany, Turkey.
\end{tabular}

JEL Classification:

J63, J21, J24, M12, 015, P59

\begin{abstract}
A B S T R A C T
In this study, the extent of flexible working patterns beginning to replace the conventional working models is examined in companies in Turkey and Germany. The extent of flexible working patterns in the two countries is also compared. The objectives of the study are to determine the prevalence of these patterns and to find out the similarities and differences regarding flexible working in the two countries. The flexible working patterns focused on in this study are weekend work, shiftwork, overtime work, part-time work, job sharing, flexitime, fixed-term contracts, home-based work, telecommuting, and compressed workweeks. The research, which is designed with the last round database of the CRANET Survey on Comparative Human Resource Management Research, includes the companies in Turkey and Germany of the 35 participating countries (154 companies from Turkey and 278 companies from Germany which makes a total of 432 companies). In the findings section, first of all, the prevalence of each flexible working pattern in the two countries has been presented. Chi-square analysis has been conducted for each of the flexible working patterns to find out if there are any significant differences in the prevalence of these models in the two countries. As a result, it is determined that the extent of the nine flexible working patterns differed in the two countries. This is to say that the prevalence of several flexible working patterns ensuring the work-life balance of the employees is higher in Germany whereas flexible patterns used for economic reasons and do not add value to the work-life balance of the employees are usually prevalent in Turkey. The only similarity between the two countries is the use of home-based work.
\end{abstract}

(C) 2020 by the authors. Licensee SSBFNET, Istanbul, Turkey. This article is an open access article distributed under the terms and conditions of the Creative Commons Attribution (CC BY) license (http://creativecommons.org/licenses/by/4.0/).

\section{Introduction}

As economic, social and technological advances have taken place for the last 40 years, different forms of employment have been required around the world. These flexible working patterns, in other words forms of atypical employment models, have been used since 1970's by especially European countries. Of all the other countries, Germany has a unique role in flexible working patterns (Tuncay, 1999; Centel, 1999; Ertürk, 2000; Prinz, 2006) for the first application of these models has taken place in "MessercshmittBolkow-Blohm" company in Germany in 1967 (Uyargil, 1984; Yavuz, 1999). Since then, Germany has been a country where flexible working patterns have been used widely. Comprehensive regulations have also long been established in Germany. For instance regulations regarding flexible patterns came into force in 1994 with the enactment of Working Time Law in Germany (Centel, 1999) whereas in Turkey regulations regarding most of the flexible working patterns were established in 2003 with the enactment of the Labor Law no. 4857.

Flexibility in working life has come into question especially in Europe after the oil crisis in 1973 (Centel, 1999). Nowadays as pandemic caused by COVID-19 effects working life all over the world, flexible working patterns are being used worldwide. However, this article deals with the situation regarding flexible patterns before the pandemic in 2020.

It is clearly seen that flexible working patterns are required due to force majeure reasons such as global pandemic as well as economic crises and changing workforce needs and expectations. Due to the increasing number of dual-career couples, need for work-life balance, companies need to apply flexible working schedules. Therefore, current situation regarding the use of flexible working

* Corresponding author. ORCID ID: 0000-0002-5487-6345

(C) 2020 by the authors. Hosting by SSBFNET. Peer review under responsibility of Center for Strategic Studies in Business and Finance. https://doi.org/10.20525/ijrbs.v9i4.714 
patterns is examined in this study. Large-scale companies in Germany and Turkey have been analyzed in the research. In order to determine their use of flexible working models where Germany has historically extensive use of these patterns whereas in Turkey those practices are getting more attention since 2003.

The data of the CRANET Survey on Comparative Human Resource Management Research have been used in this study. Specifically, 432 companies (154 companies from Turkey and 278 companies from Germany) have participated in the research from both countries. The data have been analyzed via chi-square analysis and the prevalency of 10 flexible working patterns focused in this study has been compared. The most common flexible working patterns are considered to be weekend work, shiftwork, overtime work, part-time work, job sharing, flexitime, fixed-term contract, home-based work, telecommuting and compressed workweeks. Following sections of this study include literature review, methodology and findings sections. In the literature review section, each of the flexible working patterns has been examined from the legal and theoretical perspectives and afterwards, the prevalency regarding each of these patterns in the two countries have been presented in the findings section. Additionally, chi-square analysis has been conducted to find out if there are any statistically significant differences in the use and prevalency of these patterns in the two countries.

\section{Literature Review}

Flexible working patterns have been used since late 1960's and the oil crisis in 1973 has increased the cruciality of flexibility. Economic crisis, change in the structure, behaviors and expectations of the workforce have also led the use of flexible working patterns (Papalexandris \& Kramar, 1997).

Traditionally, several flexible working patterns such as part-time work and temporary working are provided mostly to women and young employees (Ekin, 1999; Tuncay, 1999). Technological advances also enable companies use these flexible working patterns (Aktay, 1999; Iş1k, 2003).

Some patterns those are considered to be "flexible" such as overtime work, shiftwork, fixed-term contracts and weekend work had always been in use traditionally. Some argue if these traditional patterns are flexible in nature or not (Hill et al., 2008; Young, 1980; Shields, 2002). Since employers provide flexible working patterns due to economic crisis, the main objective for the employers is cost-reduction. On the other hand, employees would prefer flexible working patterns for spare time, autonomy and work-life balance (Uyargil, 1984). Technological advances enable to use these models which both parties (employers and employees) with conflicting objectives prefer for different reasons. In the current situation, millions of people worldwide are forced to work at home due to pandemic caused by COVID-19. This tragic case also reminds us for the cruciality of flexible working patterns.

This study contributes to the literature on flexible patterns on two ways: Firstly, by distinguishing the perspectives regarding "flexible" working patterns which are required to ensure work-life balance of the employees, on the other hand to ensure costreduction from the employers' view point. Secondly, by analysing the differences in the use of these models in two different countries (Germany and Turkey) indicating the current prevalency of flexible patterns in the two countries.

In our study flexible working patterns are studied under the headings of weekend work, shiftwork, overtime work, part-time work, job sharing, flexitime, fixed-term contract, home-based work, telecommuting and compressed workweeks.

\section{Weekend Work}

According to classical employment patterns almost all countries provide a minimum period of weekly rest. The vast majority of these require that it to be one day in length and in principle be taken on a Sunday (McCann, 2005). However, in fields such as retail, food and tourism working, where working on Sundays became a necessity, weekend work is considered flexible working. (Işsk, 2003; Demircioğlu \& Engin, 2002)

The regulations which allowing weekend work require a rest period of at least 24 hours each week. Thus, the Weekly Rest (Industry) Convention, 1921 No.14, and Weekly rest (Commerce and Offices) Convention, 1957 (No.106) are permitting a rest period of at least 24 hours each week (McCann, 2005). Turkish Labor Law no. 4857, article number 46 defines week holiday in this manner. Regular weekend work is still the exception for the vast majority of the workforce, a gradual, step-by-step advance in the number of weekend shifts cannot be ignored.

In Germany employees who are working during the weekends are allowed to take a rest period at least 24 hours each week. On the other hand, the law permits them to take minimum 15 Sunday in one year as rest day, taking into consideration the employee's needs (The Working Time Act (Arbeitszeitgesetz) Article 11).

\section{Shiftwork}

As a traditional working pattern, shiftwork is especially required in industries such as health, tourism and telecommunication industries (Brewster, Mayne \& Tregaskis, 1997). In spite of that companies arrange the working period as shifts due to sustainability of their activities, shiftwork is considered to be a reason provoking increasing job stress (Richter et al., 2010). In shiftwork at least two workers share the same job by regularly shifting due to a shift plan (Prinz, 2006). 4857 no. Labor Law covers regulations related to shiftwork in Article 69 enabling shiftwork in Turkey. The Working Time Act in Germany also enables shiftwork due to Article 6. 
According to German Economics Institute, \% 10,7 of the employees in Germany were provided shiftwork in 1999 (Prinz, 2006 ). It is also stated that $\% 30$ of the working population are employed in shifts (Richter et al., 2010).

\section{Overtime Work}

Overtime refers to employees working additional hours beyond their standard schedules which is indicated either by law or by individual labor agreements. Overtime has to be compensated for with additional time off or by overtime bonus (Prinz, 2006).

Overtime is a flexible working pattern which allows companies instead of recruiting new personnel to use their current employees in order to overcome production or service fluctuations. In other words, employee overtime is one of the quickest ways to handle labor shortages.

Overtime work shows different characteristics not only according to countries but also criteria when it can be performed or the procedures that should be followed. In some countries overtime is prohibited for certain groups of employees because of health and safety concerns and in some countries there are time limit restrictions for overtime work. In Turkey, 4857 no. Labor Law limits overtime work stating "maximum 270 hours yearly" per each employee (Acar, Aydınlı \& Yıldırım, 2005).

The Hours of Work (Industry) Convention (No.1), Hours of Work Convention No.30, and Reduction of Hours of Work Recommendation (No.116) of ILO are the international standards for overtime work (http://www.ilo.org/ilolex/english/convdisp1.htmhttp:www.ilo.org; McCann, 2005).

According to the regulations in Germany, the hours in a working day may be extended to a maximum of 10 hours if, over six calendar months or within 24 weeks, an average of eight hours per working day is not exceeded. (The Working Time Act, Article 3). When the issue in application has been explored in Germany, in 2002 each employee exceeds predetermined hours by the collective agreements in average 100 hours more (Prinz, 2006).

Beside the flexibility advantage, the pitfalls of overtime work are high dissatisfaction levels and safety problems, should also be taken into account (Güzel, 2000). The national regulations in order to prevent the abuse of the overtime work, consider not too much ease the legal rules.

\section{Part-Time Work}

As the most widely used flexible working pattern (Brewster, Mayne \& Tregaskis, 1997), part-time work can be defined as jobs with significantly less amount of hours than the determined hours per week. Definitions of part-time work are based on either on hours thresholds or on an assessment by the respondent of the nature of the job, or both for several countries (Bastelaer et al. 1997). According to ILO Convention no. 175 dated 24 June 1994, a part-timer is an employee who works less hours in a week when compared to the avarege full-time worker (http://www.ilo.org/ilolex/english/convdisp1.htm). Part-timers are employees who work less hours than the determined hours for normal weekly period in Turkey and Germany. As the definitions and practices of part-time work differ in several countries (Brewster, Mayne \& Tregaskis, 1997), working up to 38 hours per week in Germany (Aktay, 1999) and working up to 30 hours per week in Turkey are considered as part-time work.

Regulations regarding part-time work in Germany dates back to 1985 (Ertürk, 2000). Historically the development of part-time work in Germany stems/derives from the West side. In the East Germany full-time employment was the norm until 1990's (Visser \& Yerkes, 2008). In Germany, part-time employment is widely used especially by women employees and there is an increasing trend in part-time work (Visser \& Yerkes, 2008).

In EU countries \% 14,9 of the workforce were part-timers in 2002. In 2018 the ratio of part-timers increased to \% 18,5 (Eurostat). In Germany part-timers constituted \% 16,6 of the workforce in 1998 (Jung, 2001) whereas the same ratio was \% 26,6 in 2014 (Eurostat).

\section{Job Sharing}

Job sharing can be considered as a special form of part-time work or in other words "sharing the workplace", which means minimum two employees perform the work of one full-time job (Mathis \& Jackson, 2007; Özgener, 2005). The employees who are part of this work pattern, based on the predetermined or scheduled program and time planned will work in shifts by conducting the same job (Prinz, 2006). Thus, the job will be completed without interruptions by fulfilling the job requirements (Özgener, 2005).

Currently, Turkish Labor Law does not regulate specifically job sharing. However, there is no legal obstruction to applying job sharing (Tuncay, 1999). In Germany job sharing work pattern is regulated in under the title of part-time and definite term employment law. Accordingly, any kind of organizational risks arise within the employee absence, belong only the employer. Thus, it can be stated that, job sharing in comparison to other flexible patterns is less prevalent in Germany (Prinz, 2006).

\section{Flexitime}

In spite of that general tendency in flexibility is to decrease working time (hours), nowadays it seems to be more important to flex working period (McCann, 2005). Flexitime arrangements involves an alternative for the employees to start working and end up working at the same time. Instead, employees have opportunities to determine their own working periods (Yavuz, 1999). Flexitime 
arrangements involve a core working period when all the employees should be working at the same time (Uyargil, 1984) and additionally there are flexible hours they can prefer to work for (Yavuz, 1999).

Flexitime arrangements are seen in Germany in 1967 as the first example of flexible working patterns. In 1980\% 40-45 of the workforce are provided flexitime arrangements in Germany (Yavuz, 1999). Examining the legal framework regarding flexible working hours in Germany and Turkey, it is seen that in both countries regulations enable companies to use flexitime arrangements.

\section{Fixed-Term Contracts}

Fixed-term contract is one that ends on an agreed date. The period of such a contract may range from a matter of months up to a period of a year or more. It may be based on a future event which marks the end of the contract and whose occurrence is beyond the control of the parties (www.uslegal.com). It is a flexible working pattern where parties agree to terminate the agreement in a specified date explicitly or the completion of a certain job or to the provision of a certain service (Tuncay, 1999). Essentially, fixed-term employment contracts are not considered as a new employment type. In 1980's the rise of unemployment due to the economic turbulences lead the authorities to reconsider these types of agreements as a flexible work pattern (Tuncay, 1999).

Definite time of work has been restricted according to some conditions in various countries employment legislation systems (Ekin, 1999). In other words, fixed-term employment contracts are implemented only under the legitimate protection and these types of agreements are accepted as a distinction (Demircioğlu \& Engin, 2002, Tuncay, 1999). Because employees working with the fixedterm employment contract are excluded from some employee-friendly practices like job security, severance payment.

At the European Union level, the definition of fixed- term contract is first accepted in 25 June 1991 with the regulation numbered 91/383/EEC Council Directive titled "Supplementing The Measures To Encourage Improvements In The Safety And Health At Work Of Workers With A Fixed-Duration Employment Relationship Or A Temporary Employment Relationship". With this particular Directive, at the EU level, the establishment of the agreement to an objective reason has been firstly accepted (Aktekin, 2006). At the EU level social parties are signed the framework agreement on Fixed-Term Work in 18 March 1999 and this agreement became binding among the member states. With this provision the Directive dated 28 June, 1999 and numbered 99/70/EC accepted, the signatory parties have demonstrated a desire to improve the quality of fixed-term work by ensuring the application of the principle of non- discrimination and to establish a framework to prevent the abuse of successive fixed-term employment contracts and relationships (Aktekin, 2006).

In parallel with these improvements within EU, Germany in 2001 amended a law regarding the Part-Time Work and Fixed-Term Employment Contract. With this law, in order to sign a fixed-term employment contract, the legitimate reasons like, the need for temporary employees, the content of work, the reasons related to employees, should be declared (Demircioğlu \& Engin, 2002). As well as Germany, signing fixed-term contracts has been limited to the presence of objective reasons in Turkey in 2003 with 4857 no. Labor Law.

\section{Alternative Work Locations (Telecommuting, Home-Based Work)}

Due to the developments in communication technology, employees are not obliged to work only within the company buildings or offices. From the last decade, many organizations allow their employees to work at locations other than company facilities. Employees can work at home, which is the most common arrangement. However, people can work, not only in their houses, but in other places as well. This practice is called telecommuting (telework), since employees are connected with the office through voice or data lines such as telephone and high-speed internet connections (Stewart \& Brown, 2011; Lim \& Teo, 2000). Telework is defined (in the 2002 European cross sector social partner's framework agreement on telework) as a form of organizing and/or performing work, using information technology, in the context of an employment contract/relationship, where work, which could also be performed at the employer's premises, is carried out away from those premises, on a regular basis. The agreement also defines a teleworker as a person carrying out telework according to the definition given. The characteristic feature of telework is the use of computers and telecommunications to change the usual location of work (https://www.eurofound.europa.eu/observatories/eurwork/industrial-relations-dictionary/telework).

Telecommuting offers many benefits to companies and employees. The most important benefit is that it provides flexibility in the hours and location at work. Because employees can work from home or from satellite location, they do not have to spend time commuting to and from a particular site (Lepak \& Gowan, 2010). Some people might have some problems at commuting to a traditional 9-to-5 workday due to their family responsibilities. So with this flexible working alternative, they can work and be at home to carry on their responsibilities.

There are some drawbacks regarding telecommuting, especially it is really costly to set up such system by providing computers, internet services to employees' houses. Smaller firms will have difficulties in providing these technologies to their employees. It is also possible that relying too much on telecommuting may erode the environment at work (Lepak \& Gowan, 2010). Another problem with working at home is the sense of isolation that some workers experience. These workers feel that they miss out on important social interaction and in some cases, they think that their contributions are less likely to be noticed and rewarded. Employees feel less connected (Stewart \& Brown, 2011). 
For many years mostly women have worked from their home, in order to provide additional income to their houses. They were involved to produce small handcrafts, to prepare food to small restaurants, or they were sewing dresses to their customers. Over the years because of the developments within the various industries, people working from their home they had to difficulties to sell their products, consequently resulted less need for these people products. Maybe that's why we hardly remember those household people products. Now the term has shifted to a new meaning, just working from home. The employer fixes the work site as a home by providing the employees the required infrastructure. In other words, because of the improvements within communication technology the working site could be either your home or another location set by the employer. Compulsory reasons may also cause people to work at home coerciblely as experienced in pandemic process in 2020.

\section{Compressed Workweek}

Compressed workweek is an alternative schedule, in which employees work fewer days, but longer hours each day, instead of working 5 or 6 days a week (Gümüş, 2005; Baltes et al. 1999). Working hours per week are not shortened (Özgener, 2005), but distributed to fewer days (Gümüş, 2005). In this way employees go to work on fewer days. Legal regulations in both countries also enable companies to provide compressed workweek arrangements for their employees (Labor Law no. 4857, Article 63 in Turkey and Working Time Law, Article 3 in Germany).

\section{Research and Methodology}

The objectives of the study are to determine the use of these models in the Germany and Turkey and to determine the similarities and differences between the two countries in terms of practicing these flexible patterns.

This study uses data from the CRANET survey on Comparative Human Resource Management (HRM) research. CRANET questionnaire has been a multi-purpose large-scale repeated cross-country survey conducted since 1989. 35 countries participated in the last round of this research. The questionnaire includes questions about all aspects of HRM. Since our interest is on flexible working patterns in Germany and Turkey, we restrict our analyses to this subject and to these two countries. The sample in Turkey covers 1000 large-scale companies from Istanbul Chamber of Industry (ISO) and 150 Istanbul Stock Exchange Market (Borsa Istanbul) companies. On the other hand, the questionnaires were sent to 4000 large-scale companies in Germany. 154 large-scale companies from Turkey and 278 large-scale companies from Germany participated in the research with a total of 432 companies.

The data were collected from these 432 companies through questionnaire method. For the purpose of this study, we use 10 flexible working patterns as dependent variables. These are; weekend work, shiftwork, overtime, part-time work, job sharing, flexitime, fixedterm contracts, home-based work, telecommuting and compressed workweek. In addition to these dependent variables, the "country" variable as an independent variable is used in the analysis. Based on these variables, the hypotheses of the research are formulated as follows:

H0: There is no statistically significant difference in the prevalence of flexible working patterns between the companies in Turkey and Germany.

H1: There is a statistically significant difference in the prevalence of flexible working patterns between the companies in Turkey and Germany.

According to these hypotheses, the prevalence of each flexible working patterns in the two countries is compared. It is investigated if any differences occur on the prevalence of these patterns in the two countries via chi-square analysis.

\section{Findings}

In this research, the extent of flexible working models used in companies from Germany and Turkey is examined and compared via chi-square analysis. First of all, participant companies are compared according to the extent of the use of weekend work.

Table 1: Weekend Work

\begin{tabular}{|c|c|c|c|c|c|c|c|c|}
\hline & & & \multicolumn{5}{|c|}{ Weekend Work } & \multirow[t]{3}{*}{ Total } \\
\hline & & & Not used & Between & Between & Between & & \\
\hline & & & & $\% 1-10$ & $\% 11-20$ & $\% 21-50$ & $>\% 50$ & \\
\hline & Germany & $\mathrm{f}$ & 74 & 99 & 30 & 23 & 40 & 266 \\
\hline \multirow[t]{3}{*}{ Country } & & $\%$ & $\% 27,8$ & $\% 37,2$ & $\% 11,3$ & $\% 8,6$ & $\% 15$ & $\% 100,0$ \\
\hline & Turkey & $\mathrm{f}$ & 35 & 33 & 13 & 16 & 40 & 137 \\
\hline & & $\%$ & $\% 25,5$ & $\% 24,1$ & $\% 9,5$ & $\% 11,7$ & $\% 29,2$ & $\% 100,0$ \\
\hline \multirow[t]{2}{*}{ Total } & & $\mathrm{f}$ & 109 & 132 & 43 & 39 & 80 & 403 \\
\hline & & $\%$ & $\% 27$ & $\% 32,8$ & $\% 10,7$ & $\% 9,7$ & $\% 19,9$ & $\% 100,0$ \\
\hline
\end{tabular}


Examining Table 1, it is seen that companies from Germany and Turkey widespread work at the weekend. In Turkey, \% 29 of the companies have majority of their employees work at the weekend whereas only $\% 15$ of the companies from Germany have the majority of their workforce work at the weekend. According to the chi-square analysis results (See Table 1a), there is a significant difference between the companies from Germany and Turkey regarding their weekend work usage (since $0,004<0,05$ ). As a result, a higher proportion of the companies from Turkey use weekend work more widespread when compared to the companies from Germany.

Table 1a: Chi-Square Tests (Weekend Work)

\begin{tabular}{|c|c|c|c|}
\hline & Value & Df & Asymp. Sig. \\
\hline Pearson Chi-Square & 15,196 (a) & 4 & 0,004 \\
\hline Likelihood Ratio & 14,945 & 4 & 0,005 \\
\hline $\mathbf{N}$ & 403 & & \\
\hline
\end{tabular}

(a) 0 cells $(0,0 \%)$ have expected count less than 5. The minimum expected count is 13,26.

A recent research by Aydinlı (2007) supports these results indicating the difference between the extend of weekend work usage of companies from Germany and Turkey. As a result, there seems to be no significant difference between the two countries has occured since 2007 regarding weekend work.

Table 1b: Industries Working at Weekend

\begin{tabular}{lcc}
\hline Industries & Germany & Turkey \\
\hline Production & $\% 22$ & $\% 64$ \\
\hline Health & $\% 24$ & - \\
\hline Retail & $\% 22$ & $\% 15$ \\
\hline Other (telecommunication, food, chemicals, transportation, warehouse etc) & $\% 32$ & $\% 21$ \\
\hline
\end{tabular}

It is also examined in Table $1 \mathrm{~b}$ in which industries weekend work is preferred more in the two countries. In Turkey $\% 64$ of the companies use weekend work in production industry especially in metal production. Retail industry follows production industry with a ratio of $\% 15$ in Turkey. In Germany \% 24 of the companies that use weekend work is operating in health industry whereas $\% 22$ of the companies are operating in production industry (especially metal production similar to Turkey). In Germany \% 22 of the companies using weekend work are from retail industry.

Table 2: Shiftwork

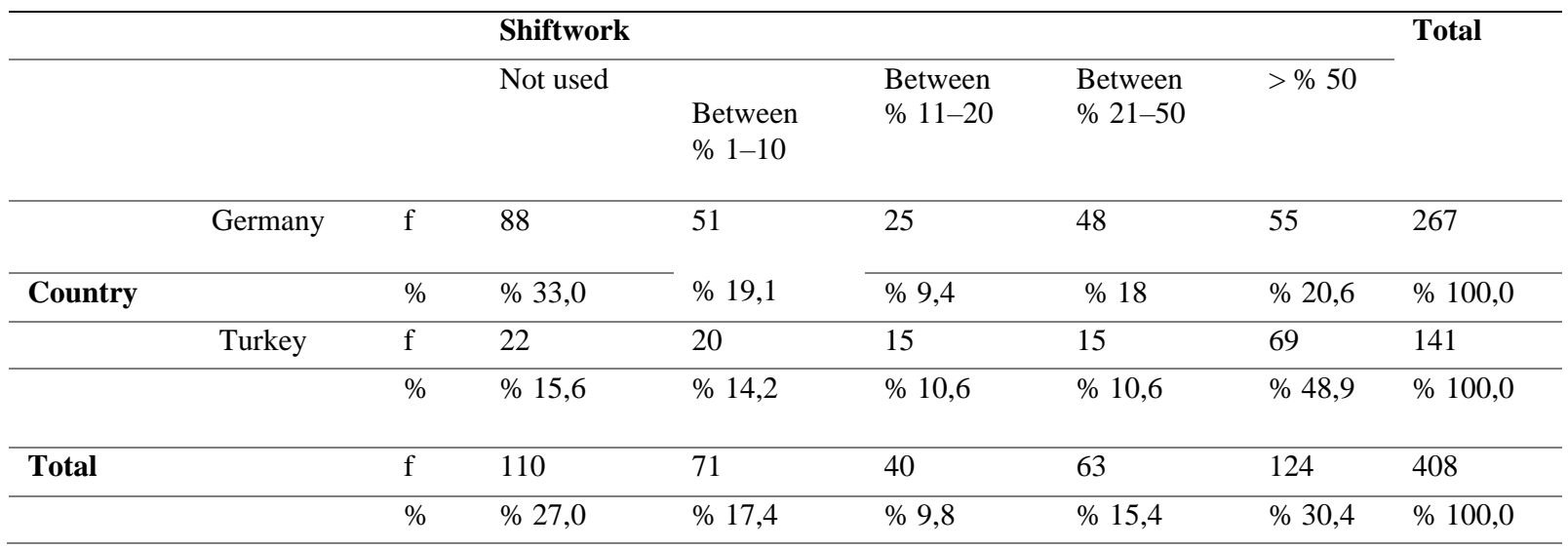

Examining Table 2, it is seen that shiftwork is prevalently used in the two countries as the regulations in both of these countries allow companies to use this pattern. On the other hand, chi-square analysis results show that a significant difference $(0,000<0,05)$ occurs between the companies from the two countries indicating that companies in Turkey use shift work more widespread (See Table 2a). Moreover, nearly half of the companies (\% 49) in Turkey apply this pattern to majority of their workforce. Shiftwork provides especially industrialized companies use technological hardware in a more efficient way (Prinz, 2006). Therefore, in such developing countries like Turkey, more prevalently use of shiftwork is an expected result considering efficiency of resources. Moreover, it is not surprising that shiftwork, as one of the most "traditional" flexible working patterns (Demircioğlu \& Engin, 2002; Aktay, 1999), is frequently used by companies in the two countries. It should also be considered that these traditional patterns such as shift work, 
overtime etc. are not accepted as "flexible" working patterns according to several views since they do not add value the employees' work-life balance.

Table 2a: Chi-Square Tests (Shiftwork)

\begin{tabular}{|c|c|c|c|c|}
\hline & Value & Df & Asymp. Sig. & (2-sided) \\
\hline Pearson Chi-Square & 39,342 (a) & 4 & 0,000 & \\
\hline Likelihood Ratio & 39,140 & 4 & 0,000 & \\
\hline $\mathbf{N}$ & 408 & & & \\
\hline
\end{tabular}

Table 3: Overtime

\begin{tabular}{|c|c|c|c|c|c|c|c|}
\hline \multirow[b]{2}{*}{ Country } & & \multicolumn{5}{|l|}{ Overtime } & \multirow[t]{2}{*}{ Total } \\
\hline & & Not used & $\begin{array}{l}\text { Between } \\
\% 1-10\end{array}$ & $\begin{array}{l}\text { Between } \\
\% \text { 11-20 }\end{array}$ & $\begin{array}{l}\text { Between } \\
\% \text { 21-50 }\end{array}$ & $>\% 50$ & \\
\hline \multirow[t]{2}{*}{ Germany } & $\mathrm{f}$ & 135 & 71 & 28 & 11 & 17 & 262 \\
\hline & $\%$ & $\% 51,5$ & $\% 27,1$ & $\% 10,7$ & $\% 4,2$ & $\% 6,5$ & $\% 100,0$ \\
\hline \multirow[t]{2}{*}{ Turkey } & f & 9 & 34 & 32 & 33 & 29 & 137 \\
\hline & $\%$ & $\% 6,6$ & $\% 24,8$ & $\% 23,4$ & $\% 24,1$ & $\% 21,2$ & $\% 100,0$ \\
\hline \multirow[t]{2}{*}{ Total } & $\mathrm{f}$ & 144 & 105 & 60 & 44 & 46 & 399 \\
\hline & $\%$ & $\% 36,1$ & $\% 26,3$ & $\% 15,0$ & $\% 11,0$ & $\% 11,5$ & $\% 100,0$ \\
\hline
\end{tabular}

It is clearly seen from Table 3 that companies in Turkey widespread (\% 93,4) use overtime work. On the other hand, most of the companies (\% 51,5) in Germany do not use overtime. According to the chi-square analysis results, the difference between the two countries is statistically significant as $p=0,000<0,05$. (See Table 3a). Examining the trend in overtime work since 2007, the trend in Germany indicates a decrease whereas the trend in Turkey indicates an increase (Aydinl1, 2007). In other words, more companies in Turkey make their employees work overtime, on the other hand in Germany majority of the companies do not make their employees work overtime, so the extend of overtime work has decreased since 2007.

Since overtime work is preferred by companies and is accepted by employees for economic reasons, it is not surprising for the companies in Turkey that they widespread use this model. As a general observation, employees do not usually prefer to have spare time for overtime work. Instead of having spare time, they usually prefer to be paid extra for overtime work. As an overview, the results regarding overtime work indicates work-life balance in Germany.

Table 3a: Chi-Square Tests (Overtime)

\begin{tabular}{llll}
\hline & Value & df & Asymp. Sig. \\
& & & \\
\hline Pearson Chi-Square & 109,247 (a) & 4 & 0,000 \\
\hline Likelihood Ratio & 120,734 & 4 & 0,000 \\
\hline $\mathbf{N}$ & 399 & & \\
\hline
\end{tabular}

(a) 0 cells $(0,0 \%)$ have expected count less than 5. The minimum expected count is 15,11

Table 4: Part-Time Work

\begin{tabular}{|c|c|c|c|c|c|c|c|}
\hline \multirow[b]{2}{*}{ Country } & & \multicolumn{5}{|c|}{ Part-Time Work } & \multirow[t]{2}{*}{ Total } \\
\hline & & $\begin{array}{l}\text { Not } \\
\text { used }\end{array}$ & $\begin{array}{c}\text { Between } \\
\% 1-10\end{array}$ & $\begin{array}{l}\text { Between } \\
\% \text { 11-20 }\end{array}$ & $\begin{array}{l}\text { Between } \\
\% \text { 21-50 }\end{array}$ & $>\% 50$ & \\
\hline \multirow[t]{2}{*}{ Germany } & $\mathrm{f}$ & 3 & 117 & 81 & 52 & 13 & 266 \\
\hline & $\%$ & $\% 1,1$ & $\% 44,0$ & $\% 30,5$ & $\% 19,5$ & $\% 4,9$ & $\% 100,0$ \\
\hline Turkey & $\mathrm{f}$ & 44 & 35 & 5 & 1 & 0 & 85 \\
\hline
\end{tabular}




\begin{tabular}{ccccccccc}
\hline & $\%$ & $\% 51,8$ & $\% 41,2$ & $\% 5,9$ & $\% 1,2$ & $\% 0,0$ & $\% 100,0$ \\
\hline Total & $\mathrm{f}$ & 47 & 152 & 86 & 53 & 13 & 351 \\
\hline & $\%$ & $\% 13,4$ & $\% 43,3$ & $\% 24,5$ & $\% 15,1$ & $\% 3,7$ & $\% 100,0$ \\
\hline
\end{tabular}

A typical flexible working model supporting work-life balance is undoubtedly part-time work. Examining the use of part-time work in the two countries, it is clearly seen from Table 4 that almost all participant companies in Germany $(\% 98,9)$ use part-time work whereas this model is used by almost half of the participant companies in Turkey (\% 48,2). The chi-square analysis results indicate that the difference in the use of part-time work in the two countries is statistically significant since $p=0,000<0,05$ (See Table $4 a$ ). Examining the results regarding part-time work in the previous research by Aydınl1 (2007), it is seen that almost all the companies in Germany $(\%$ 98,2) used part-time work, on the other hand, only \% 23,6 of the companies in Turkey used part-time work in 2007. So it is clearly seen that since 2007, use of part-time work in companies in Turkey increased to a great extent. It should also be considered that the regulations regarding part-time work in Turkey took place in Labor Law no. 4857 in 2003. So several companies have begun to use part-time work since then and the extend of part-time work has increased since 2007 supporting our previous expectations (Aydınl, 2007). On the other hand, the prevalent use of part-time work in companies in Germany can be attached to institutional background of the patterns due to comprehensive regulations that have been in force since 1985 (Ertürk, 2000).

Table 4a: Chi-Square Tests (Part-Time Work)

\begin{tabular}{|c|c|c|c|}
\hline & Value & Df & $\begin{array}{l}\text { Asymp. Sig. } \\
\text { sided) }\end{array}$ \\
\hline Pearson Chi-Square & 157,890 (a) & 4 & 0,000 \\
\hline Likelihood Ratio & 154,177 & 4 & 0,000 \\
\hline
\end{tabular}

(a) 1 cell $(10 \%)$ has expected count less than 5 . The minimum expected count is 3,15 .

In spite of that the regulations regarding specifically job sharing do not exist in Turkey, it is surprising to see $\% 53$ of the companies use job sharing. Even though Germany has a legal framework regarding job sharing, we expect to see more frequent use of job sharing compared to Turkey. However, job sharing is used more prevalently in Turkey than in Germany based on the chi-square analysis results in Table 5a indicating the difference between the two countries $(\mathrm{p}=0,000<0,05)$.

Table 5: Job Sharing

\begin{tabular}{|c|c|c|c|c|c|c|c|}
\hline \multirow[b]{2}{*}{ Country } & & \multicolumn{5}{|c|}{ Job Sharing } & \multirow[t]{2}{*}{ Total } \\
\hline & & Not used & $\begin{array}{c}\text { Between } \\
\% 1-10\end{array}$ & $\begin{array}{l}\text { Between } \\
\% 11-20\end{array}$ & $\begin{array}{l}\text { Between } \\
\% \text { 21-50 }\end{array}$ & $>\% 50$ & \\
\hline \multirow[t]{2}{*}{ Germany } & f & 182 & 74 & 10 & 2 & 0 & 268 \\
\hline & $\%$ & $\% 67,9$ & $\% 27,6$ & $\% 3,7$ & $\% 0,7$ & $\% 0,0$ & $\% 100,0$ \\
\hline \multirow[t]{2}{*}{ Turkey } & $f$ & 64 & 26 & 25 & 11 & 11 & 137 \\
\hline & $\%$ & $\% 46,7$ & $\% 19,0$ & $\% 18,2$ & $\% 8,0$ & $\% 8,0$ & $\% 100,0$ \\
\hline \multirow[t]{2}{*}{ Total } & $\mathrm{f}$ & 246 & 100 & 35 & 13 & 11 & 405 \\
\hline & $\%$ & $\% 60,7$ & $\% 24,7$ & $\% 8,6$ & $\% 3,2$ & $\% 2,7$ & $\% 100,0$ \\
\hline
\end{tabular}

Table 5a: Chi-Square Tests (Job Sharing)

\begin{tabular}{lccc}
\hline & Value & Df & $\begin{array}{c}\text { Asymp. Sig. } \\
\text { sided) }\end{array}$ \\
\hline Pearson Chi-Square & & 4 & 0,000 \\
\hline Likelihood Ratio & $68,048(\mathrm{a})$ & 4 & 0,000 \\
\hline $\mathbf{N}$ & 68,624 & 405 & \\
\hline
\end{tabular}

(a) 2 cells $(20 \%)$ have expected count less than 5 . The minimum expected count is 3,72 . 
Table 6: Flexitime

\begin{tabular}{|c|c|c|c|c|c|c|c|}
\hline \multirow[b]{2}{*}{ Country } & & \multicolumn{5}{|c|}{ Flexitime } & \multirow[t]{2}{*}{ Total } \\
\hline & & $\begin{array}{l}\text { Not } \\
\text { used }\end{array}$ & $\begin{array}{c}\text { Between } \\
\% 1-10\end{array}$ & $\begin{array}{l}\text { Between } \\
\% \text { 11-20 }\end{array}$ & $\begin{array}{l}\text { Between } \\
\% \text { 21-50 }\end{array}$ & $>\% 50$ & \\
\hline \multirow[t]{2}{*}{ Germany } & $\mathrm{f}$ & 17 & 28 & 30 & 43 & 153 & 271 \\
\hline & $\%$ & $\% 6,3$ & $\% 10,3$ & $\% 11,1$ & $\% 15,9$ & $\% 56,5$ & $\% 100,0$ \\
\hline \multirow[t]{2}{*}{ Turkey } & $\mathrm{f}$ & 85 & 25 & 5 & 12 & 9 & 136 \\
\hline & $\%$ & $\% 62,5$ & $\% 18,4$ & $\% 3,7$ & $\% 8,8$ & $\% 6,6$ & $\% 100,0$ \\
\hline \multirow[t]{2}{*}{ Total } & $f$ & 102 & 53 & 35 & 55 & 162 & 407 \\
\hline & $\%$ & $\% 25,1$ & $\% 13,0$ & $\% 8,6$ & $\% 13,5$ & $\% 39,8$ & $\% 100,0$ \\
\hline
\end{tabular}

Table 6 indicates that flexitime arrangements are prevalently used by companies in Germany $(\% 93,7)$ whereas only a few companies in Turkey $(\% 37,5)$ have flexitime arrangements. According to the chi-square analysis results in Table $6 \mathrm{a}$, the difference between the two countries is statistically significant as $\mathrm{p}=0,000<0,05$. In both of the countries the use of flexitime arrangements is in an increasing trend since \% 22,1 of the companies in Turkey and \% 89,8 of the companies in Germany had flexitime arrangements in 2007 (Aydınl, 2007). It is not surprising that almost all participant companies in Germany have flexitime arrangements for flexitime has been used in Germany since 1967 (Yavuz, 1999).

Table 6a: Chi-Square Tests (Flexitime)

\begin{tabular}{llll}
\hline & Value & Df & Asymp. Sig. \\
\hline Pearson Chi-Square & & & \\
\hline Likelihood Ratio & 184,335 (a) & 4 & 0,000 \\
\hline $\mathbf{N}$ & 197,434 & 4 & 0,000 \\
\hline
\end{tabular}

(a) 0 cells $(0,0 \%)$ have expected count less than 5 . The minimum expected count is 11,70 .

Table 7: Fixed-Term Contracts

\begin{tabular}{|c|c|c|c|c|c|c|c|}
\hline & & \multicolumn{5}{|c|}{ Fixed-Term Contracts } & \multirow[t]{2}{*}{ Total } \\
\hline \multicolumn{2}{|l|}{ Country } & Not used & $\begin{array}{l}\text { Between } \\
\% 1-10\end{array}$ & $\begin{array}{l}\text { Between } \\
\% 11-20\end{array}$ & $\begin{array}{l}\text { Between } \\
\% \text { 21-50 }\end{array}$ & $>\% 50$ & \\
\hline & $f$ & 9 & 205 & 43 & 9 & 3 & 269 \\
\hline \multicolumn{8}{|l|}{ Germany } \\
\hline & $\%$ & $\% 3,3$ & $\% 76,2$ & $\% 16,0$ & $\% 3,3$ & $\% 1,1$ & $\% 100,0$ \\
\hline \multirow[t]{2}{*}{ Turkey } & $f$ & 44 & 73 & 10 & 3 & 6 & 136 \\
\hline & $\%$ & $\% 32,4$ & $\% 53,7$ & $\% 7,4$ & $\% 2,2$ & $\% 4,4$ & $\% 100,0$ \\
\hline \multirow{3}{*}{ Total } & $\mathrm{f}$ & 53 & 278 & 53 & 12 & 9 & 405 \\
\hline & & & & & & & \\
\hline & $\%$ & $\% 13,1$ & $\% 68,6$ & $\% 13,1$ & $\% 3,0$ & $\% 2,2$ & $\% 100,0$ \\
\hline
\end{tabular}

Examining the use of fixed term contracts, it is seen that almost all participant companies $(\% 96,7)$ in Germany use this kind of contracts. On the other hand, in Turkey fixed term contracts are used by $\%$ 67,6 of the companies. Companies from both countries heavily use fixed term contracts to between $\% 1$ and \% 10 of their employees (Germany \% 76,2 and Turkey \% 53,7). Although signing fixed term contracts is limited to objective reasons in most of the countries (Demircioğlu \& Engin, 2002; Tuncay, 1999), companies from both countries strive to use these contracts in order to control their labor costs.

Table 7a: Chi-Square Tests (Fixed-Term Contracts)

\begin{tabular}{llll}
\hline & Value & Df & Asymp. Sig. \\
\hline Pearson Chi-Square & & & \\
\hline Likelihood Ratio & $74,718(\mathrm{a})$ & 4 & 0,000 \\
\hline $\mathbf{N}$ & 72,254 & 4 & 0,000 \\
\hline
\end{tabular}

(a) 2 cells $(20 \%)$ have expected count less than 5. The minimum expected count is 3,02 . 
Table 8: Home-based Work

\begin{tabular}{lllll}
\hline \multirow{2}{*}{ Country } & \multicolumn{3}{c}{ Home-based Work } & Total \\
\hline Germany & & Not used & Used & 270 \\
\hline Turkey & $\mathrm{f}$ & 210 & 60 & $\% 100,0$ \\
\hline Total & $\%$ & $\% 77,8$ & $\% 22,2$ & 136 \\
\hline & $\mathrm{f}$ & 114 & 22 & $\% 100,0$ \\
\hline
\end{tabular}

Table 8 indicates that home-based work is used by $\% 22,2$ of the companies in Germany and \% 16,2 of the companies in Turkey. The chi-square analysis shows that no significant difference occurs in the two countries regarding the use of home-based work (See Table 8a). This model is not so prevalently used in both countries. However, comparing to Aydınl (2007) study, there is an increase in the use of home-based work, since it is more widespread used in both countries. It is to the point that the use of home-based work has increased in both countries. Nowadays employees all over the world have to work at home because of pandemic caused by COVID-19. In the current situation, even the companies that have never experienced home-based work have to make their employees work at home. Therefore, even if the prevalence of home-based work is not so high, having experience regarding this pattern would be useful nowadays.

Table 8b: Chi-Square Tests (Home-based Work)

\begin{tabular}{lllllll}
\hline & Value & df & $\begin{array}{l}\text { Asymp. Sig. } \\
\text { sided) }\end{array}$ & $\begin{array}{l}(2- \\
\text { Exact Sig. } \\
\text { sided })\end{array}$ & $\begin{array}{l}\text { (2- } \\
\text { Exact } \\
\text { (1-sided) }\end{array}$ & $\begin{array}{l}\text { Sig. } \\
\text { Pearson Chi-Square }\end{array}$ \\
\hline Continuity Correction (b) & $2,051(\mathrm{a})$ & 1 & 0,152 & & \\
\hline Likelihood Ratio & 1,693 & 1 & 0,193 & & 0,095 \\
\hline Fisher's Exact Test & 2,111 & 1 & 0,146 & 0,190 & \\
\hline $\mathbf{N}$ & & & & &
\end{tabular}

(a) 0 cells $(0,0 \%)$ have expected count less than 5 . The minimum expected count is 27,47.

(b) Computed only for a $2 \times 2$ table.

Table 9: Telecommuting

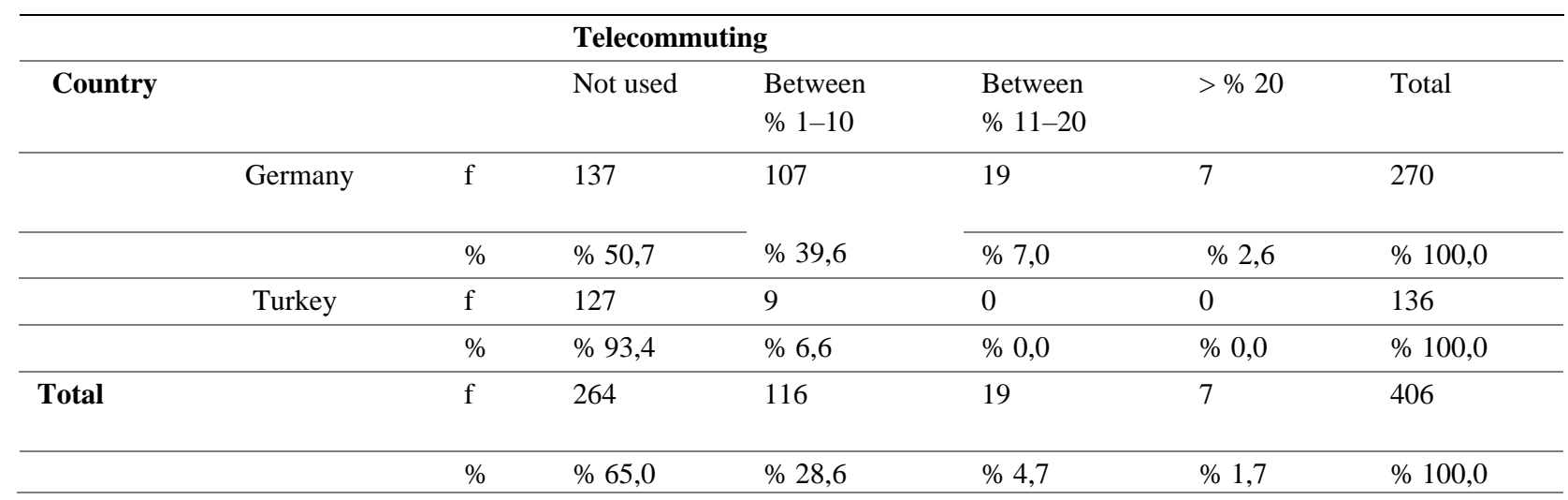

Considering technological advances in working life, telecommuting is one of the most important flexible working pattern ensuring work-life balance of employees. Examining the companies with regard to the extent of teleworking, it is seen that almost half of the companies in Germany (\% 49,3) use teleworking whereas only \% 6,6 of the companies in Turkey prefer this model. In 2007, the extend of teleworking was only \% 2,1 in companies in Turkey (Aydınlı, 2007), so we can indicate that teleworking has a low increasing trend in Turkey. Even though a little increase in the use of teleworking is determined since 2007, again the use of teleworking is so low in companies in Turkey. On the other hand, in Germany the extend of telecommuting in 2007 was \% 43,6 and now the ratio is $\% 49,3$. 
Table 9a: Chi-Square Tests (Telecommuting)

\begin{tabular}{llll}
\hline & Value & Df & Asymp. Sig. \\
& & & \\
\hline Pearson Chi-Square & 72,885 (a) & 3 & 0,000 \\
\hline Likelihood Ratio & 88,868 & 3 & 0,000 \\
\hline N & 406 & &
\end{tabular}

(a) 2 cells $(25,0 \%)$ have expected count less than 5 . The minimum expected count is 2,34 .

Table 10: Compressed Workweek

\begin{tabular}{|c|c|c|c|c|c|c|}
\hline & & & \multicolumn{3}{|c|}{ Compressed Workweek } & \multirow[t]{2}{*}{ Total } \\
\hline & & & Not used & $\begin{array}{c}\text { Between } \\
\% 1-10\end{array}$ & $>\% 10$ & \\
\hline \multirow[t]{4}{*}{ Country } & Germany & $\mathrm{f}$ & 221 & 41 & 5 & 339 \\
\hline & & $\%$ & $\% 82,8$ & $\% 15,4$ & $\% 1,9$ & $\% 100,0$ \\
\hline & Turkey & $\mathrm{f}$ & 122 & 8 & 6 & 145 \\
\hline & & $\%$ & $\% 89,7$ & $\% 5,9$ & $\% 4,4$ & $\% 100,0$ \\
\hline \multirow{2}{*}{\multicolumn{2}{|c|}{ Total }} & $\mathrm{f}$ & 343 & 49 & 11 & 403 \\
\hline & & $\%$ & $\% 85,1$ & $\% 12,2$ & $\% 2,7$ & $\% 100,0$ \\
\hline
\end{tabular}

Table 10 indicates that companies from both countries generally do not prefer to have compressed workweek as in Germany the extent of compressed workweek is only \% 17,2 and in Turkey it is only \% 10,3. The chi-square analysis shows that this difference between the two countries regarding compressed workweek is statistically significant (See Table 10a). This pattern is used by the companies when there is an urgent need due to high demands for their products or services.

Table 9a: Chi-Square Tests (Compressed Workweek)

\begin{tabular}{llll}
\hline & Value & Df & Asymp. Sig. \\
\hline Pearson Chi-Square & & & \\
\hline Likelihood Ratio & $9,288(\mathrm{a})$ & 2 & 0,010 \\
\hline $\mathbf{N}$ & 10,023 & 2 & 0,007 \\
\hline
\end{tabular}

(a) 1 cell $(16,7 \%)$ have expected count less than 5 . The minimum expected count is 3,71 .

Examining the findings as a whole, hypothesis indicating that "There is a statistically significant difference in the prevalence of flexible working patterns between the companies in Turkey and Germany." is supported to a great extent since the findings regarding only one of the ten variables indicate similarities. In other words, there is no significant difference in the prevalence of home-based work in both countries whereas there are statistically significant differences regarding the use of the remaining nine flexible patterns.

The interesting results of this study can be summarized as follows. The most prevalently used flexible pattern in Turkey is overtime, followed by shiftwork at the second rank, weekend work and fixed-term contract at the fourth rank. The least used flexible working pattern in Turkey is telecommuting, followed by compressed workweek, home-based work and flexitime. Whereas in Germany, the most prevalently used flexible pattern is part-time work which is followed by fixed-term contracts, flexitime at the third rank and weekend work. Compressed workweek is the least used work pattern in Germany, followed by home-based work, job sharing and overtime.

The results reveal that the respondent companies in Germany provide part-time work, flexitime arrangements and telecommuting models more than the respondent companies in Turkey. The common use of these flexible work patterns of the companies in Germany takes attention to rising employees' work-life quality potential by providing a work-life balance.

Specifically, part-time work which is known by its congruence to the needs of women and young labor, that is legally regulated in 2003 in Turkey, has gained popularity in recent years in Turkey. That increasing popularity has been reflected in the results of this study when compared to the previous CRANET survey Turkish results. Another remarkable result is that even though there are no specific regulations regarding job sharing in Turkey, slightly more than half of the respondent companies provide job sharing opportunities for their employees. 
As Germany is one of the first executing countries of flexitime arrangements, currently most of the companies in Germany implement flexitime model. Whereas the companies in Turkey still do not refer to this employee-friendly model as widespread as expected. This result may be because of the cultural reasons or the difficulties of setting up the system, flexitime arrangements are only used less than half of the respondents in Turkey.

The respondent companies in both countries do not use compressed workweeks widespread, which is a win-win solution for the company as well as the employee from the flexibility perspective. Another common result for both countries is that the fixed-term contracts are highly preferred by the companies. Fixed-term contracts are highly preferred especially in several industries such as textile, construction etc. in Turkey in order to control labor costs and to determine the optimal number of people in HR plans.

One of the most widely used flexible patterns all over the world is considered to be telecommuting. Almost half of the respondent companies in Germany refer to telecommuting, whereas in Turkey this ratio is still under the expectations. Another interesting result is that both countries' respondent companies rarely use home-based work arrangements. However, in 2007 there was a significant difference between the companies in Turkey and Germany regarding the use of home-based work. Specifically, less companies in Turkey provided home-based work opportunities to their employees when compared to the companies in Germany (Aydınl1, 2007). Examining the current situation (before the pandemic caused by COVID19), there is no significant difference in the use of homebased work in the two countries, that is to say prevalence of home-based work is similar in both countries. Even though the use of home-based work is not so prevalent in both countries, it can be stated that increasing number of companies provide home-based work opportunities for their employees in Turkey.

\section{Conclusions}

This study aims to compare the extent use of flexible patterns of the respondent companies in Turkey and Germany, within the context of CRANET Survey on Comparative Human Resource Management Research. The comparison resulted from the extent of the use of flexible patterns are analyzed if there are significant differences regarding the prevalence of flexible working patterns between the countries' respondent companies. As a result, it is seen that the hypothesis indicating "There is a statistically significant difference in the prevalence of flexible working patterns between the companies in Turkey and Germany." is highly supported. In a similar study conducted by Aydınl (2007) using the CRANET data, there were significant differences in the use of these ten flexible working patterns. However, in the present study it is seen that the extent use of home-based work in Turkey has increased since 2007. Especially taking into account the pandemic period, this finding indicates that some of the large-scale companies have already begun to experience home-based work in Turkey. Nowadays, most of the companies have coercively been providing home-based work opportunities because of COVID-19. Therefore, having experience regarding the use of home-based work would be beneficial in the pandemic period.

The results of this study imply that flexible working patterns can be considered from two perspectives. One is the employee-friendly approach providing work-life balance to the employees such as home-based, telecommuting, flexitime, job sharing, part-time and compressed workweeks. The other one is the employer-friendly approach including the patterns such as weekend work, shiftwork, overtime and fixed-term arrangements. The results of the respondent companies indicate that there is still a tendency to work for the sake of company/employer in Turkey. The concerns related to job security cause employees to work during the weekends, for long hours, with shifts and fixed-term contracts. Even though Turkish Labor Law allows companies to use various types of flexible patterns, employers are still reluctant to use them. With the pandemic caused by the COVID-19 virus, many employers had to refer flexible working patterns, which may lead the employers to look working life from different perspective.

The general picture on flexible work arrangements for the companies in Germany reflects both employee and employer friendly perspectives. In other words, part-time work is the most used arrangement which is an employee-friendly pattern. The secondly most preferred pattern in Germany is fixed-term contract which is an employer-friendly model. On the other hand, the third one namely flexitime is again an employee-friendly one. The companies in Germany in general use employee-friendly patterns more prevalently than the companies in Turkey.

Companies' philosophy towards flexibility will not change rapidly. As the working life changes, as the employees ask for change, as the demand for employee-friendly companies increases, the shift towards the employee-friendly flexible patterns will be fast and long-lasting. Considering the epidemic days, it is like a rehearsal of the future working life. As far as the nature of the jobs enables to work within the flexibility context, the companies would be urged to provide alternative work patterns just like during the global disease outbreak of 2020.

Finally, further studies regarding the use of flexible working patterns may focus on the effect of the use of flexible working patterns to companies' overall performance. The use and prevalence of these flexible models may also be studied according to several company demographics such as company size and various industry levels. 


\section{References}

Acar, A.C., Aydınlı, F. \& Yıldırım, O. (2005). 4857 sayılı İş Kanununda Yer Alan Başlıca Yeni Düzenlemelerin İnsan Kaynakları Yönetimi Açısından Değerlendirilmesi. İstanbul Üniversitesi İ̧sletme Fakültesi Dergisi, 34(2), 7-29.

Aktay, A.N. (1999). İş Hukukunda Esneklik Kavramının Ortaya Çıkışı ve Esneklik Uygulamaları. Mercek, Türkiye Metal Sanayicileri Sendikası, 15, 53-61.

Aktekin, Ş. (2006). Belirli Süreli İş Sözleşmesinde Objektif Neden Kavramı ve AB Uygulamaları. Sicil, Işs Hukuku Dergisi, Türkiye Metal Sanayicileri Sendikası, 42,100-105.

Aydınlı, F. (2007). Türkiye ve Almanya'daki İşletmelerde Esnek Çalışma Modellerine İlişkin Karşılaştırmalı Bir Araştırma, Yönetim, İstanbul Üniversitesi İşletme Fakültesi İşletme İktisadı Enstitüsü Dergisi, 57, 67-90.

Baltes, B. B., Briggs, T. E., HuV, J. W., Wright, J. A., \& Neuman, G. A. (1999). Flexible and compressed workweek schedules: A meta-analysis of their effects on work-related criteria. Journal of Applied Psychology, 84, 496-513. http://dx.doi.org/10.1037/0021-9010.84.4.496

Bastelaer, A., Lemaître, G. \& Marianna, P. (1997). The Definition of Part-Time Work for the Purpose of International Comparisons. OECD Labour Market and Social Policy Occasional Papers, No. 22, OECD Publishing, Paris. https://doi.org/10.1787/18151981

Brewster, C., Mayne, L. \& Tregaskis, O. (1997). Flexible Working in Europe. Journal of World Business, 32(2),133-151. https://doi.org/10.1016/S1090-9516(97)90004-3

Centel, T. (1999). Esneklik Uygulamaları ve Türkiye. Mercek, Türkiye Metal Sanayicileri Sendikası, 15, 25-32.

Demircioğlu, A.M. \& Engin, M. (2002). Dünyada ve Türkiye'de Esnek Çalışma. İstanbul Ticaret Odası, Yayın No:2002-52, İstanbul, Mega Ajans.

Ekin, N. (1999). Esneklik Çağı. Mercek, Türkiye Metal Sanayicileri Sendikası, 15, 6-14.

Ertürk, Ş. (2000). Türk İş Hukukunda Evde Çalışma. Kamu-Işs, İş Hukuku ve İktisat Dergisi, 5(3), 225-247.

Gümüş, M. (2005). Çalışma Yaşamımızda Yeni Bir Dönem: Esnek Çalışma Sürelerine Geçişte Yoğunlaştırılmış (Sıkıştırılmış) Çalışma. Mercek, Türkiye Metal Sanayicileri Sendikası, 38, 51-62.

Güzel, A. (2000). İş Hukukunda Yeniden Yapılanma Süreci ve İşin Düzenlenmesi Konusunda Esneklik. Kamu-Iş, İş Hukuku ve İktisat Dergisi, 5(3), 203-221.

Hill, E.J., Grzywacz, J.G., Allen, S., Blanchard, V.L., Matz-Costa, C., Shulkin, S. \& Pitt-Catsouphes, M. (2008). Defining and conceptualizing workplace flexibility. Community, Work and Family, 11(2), 149-163. https://doi.org/10.1080/13668800802024678

Işık, R. (2003). 'Esneklik' Üzerine Bir Not. Mercek, Türkiye Metal Sanayicileri Sendikası, 32, 107-111.

Jung, L. (2001), National Labour Law Profile: Federal Republic of Germany. http://www.ilo.org/dyn/natlex, Reached: 25th April 2004.

Lepak, D. \& Gowan, M. (2010). Human Resource Management: Managing Employees for Competitive Advantage. New York: Pearson/Prentice Hall.

Lim, V.K.G., \& Teo, T.S.H. (2000). To work or not to work at home: An empirical investigation of factors affecting attitudes towards teleworking. Journal of Managerial Psychology, 15(6), 560-566. http://dx.doi.org/10.1108/02683940010373392

Mathis, R.L. \& Jackson, J.H. (2007). Human Resource Management, 12th Edition, New York: Cengage Learning.

McCann, D. (2005). Working Time Laws: A Global Perspective (Findings from the ILO's Conditions of Work and Employment Database). Geneva, International Labour Organization.

Özgener, Ş. (2005). Çalışma Hayatında Esnekliğin İşletme Verimliliği Üzerine Etkileri: Karşılaştırmalı Bir Çalışma. TODAIEE Amme İdaresi Dergisi, 38(3), 51-79.

Papalexandris, N. \& Kramar, R. (1997). Flexible working patterns: towards reconciliation of family and work. Employee Relations, 19(6), 581-595. https://doi.org/10.1108/01425459710193126

Prinz, T., (2006), Almanya'da Esnek Çalışma Süresi Modelleri. Zülfü Dicleli, Sicil, İş Hukuku Dergisi, Türkiye Metal Sanayicileri Sendikas1, 41, 190-194.

Richter K.D., Acker J., Scholz F. \& Niklewski G. (2010). Health promotion and work: prevention of shift work disorders in companies. EPMA Journal,1(4), 611-618. https://doi.org/10.1007/s13167-010-0057-7

Shields, M. (2002). Shift work and health. Health Reports. 13(4), 11-33.

Stewart, G.L. \& Brown, K.G. (2011). Human Resource Management: Linking Strategy to Practice. New York: John Wiley and Sons, Second Edition.

Tuncay, A.C. (1999). Değişim, Esneklik ve Türkiye İçin Çözüm Önerileri. Mercek, Türkiye Metal Sanayicileri Sendikası, 15, 67-82. Uyargil, C. (1984). Modern Örgüt Yaşamında Esnek Çalışma Saatleri. İstanbul Üniversitesi İşletme Fakültesi Dergisi, 13(2), 110118.

Visser, J., \& Yerkes, M. (2008). Part-time work and the legacy of breadwinner welfare states: A panel study of women's employment patterns in Germany, the United Kingdom, and the Netherlands, 1992-2002. In L. Kenworthy, \& A. Hicks (Eds.), Method and substance in macrocomparative analysis (pp. 221-259). (Research methods series). Basingstoke: Palgrave Macmillan.

Yavuz, A. (1999). Çalışma Süresi Esnekliği ve Türleri. Mercek, Türkiye Metal Sanayicileri Sendikası, 15, 88-95.

Young, W.M. (1980). Shift work and flexible schedules: Are they compatible?. International Labor Review, 119(1), 1-24. 
Labor Law No. 4857, 10th June 2003 dated ve 25134 no. Resmi Gazete.

http://www.ilo.org/ilolex/engish/convdisp1.htm, 1st June 2006.

http://www.einclusioneu.org/ShowCase.asp?CaseTitleID=1001\&CaseID=2576\&MenuID=189 Reached: 1st June 2006.

Eurostat,https://ec.europa.eu/eurostat/statistics-explained/index.php/Employment_statistics\#Rise_in_parttime_and_temporary_work

https://www.eurofound.europa.eu/observatories/eurwork/industrial-relations-dictionary/telework Reached 28th April 2020. www.uslegal.com, Reached: 29th April 2020. 